\title{
Parasal Aktarım Mekanizması Döviz Kuru Kanalının VAR Modeli Yöntemine Göre Analizi: Türkiye, Meksika ve Endonezya Ülke Örnekleri'
}

Musa ATGÜR² - N. Oğuzhan ALTAY3

Makale Gönderim Tarihi: 16.11.2016

Makale Kabul Tarihi: 11.05.2017

\section{Öz}

Bu çalıșmada, Türkiye, Meksika ve Endonezya'da parasal aktarım mekanizması döviz kuru kanalının etkinliği VAR Modeli Yöntemi ile incelenmiștir. Çalıșmada üçer aylık veriler kullanılmıș olup, her üçülke için, 2002:I-2016:IV dönemi incelenmiștir. Elde edilen bulgular, parasal aktarım mekanizması döviz kuru kanalının Türkiye'de kısmen çalıștığını, Meksika'da ve Endonezya'da söz konusu kanalın çalıșmadığını ortaya koymuștur.

Anahtar Sözcükler: Parasal Aktarım Mekanizması, Döviz Kuru Kanalı, VAR Modeli.

The Analysis of the Exchange Rate Channel of Monetary Transmission Mechanism by VAR Model Method: Turkey, Mexico and Indonesia Examples

\section{Abstract}

This paper examines the efficiency of the monetary transmission mechanism exchange rate channel using the VAR Model Met-

1 Bu çalıșma, Musa ATGÜR'ün "Parasal Aktarım Mekanizmasının Monetarist Yaklașım Açısından FAVAR Yöntemi İle Analizi" bașlıklı doktora tezinden türetilmiștir.

2 Yrd. Doç. Dr. Necmettin Erbakan Üniversitesi, Uygulamalı Bilimler Fakültesi, matgur@konya.edu.tr

3 Prof. Dr., Ege Üniversitesi, İktisadi ve İdari Bilimler Fakültesi, oguzaltayefd@ege. edu.tr 
hod in Turkey, Mexico and Indonesia. Quarterly data were used in this paper, the period 2002:I-2016:IV for all three countries. The findings obtained show that partially works of the monetary transmission mechanism exchange rate channel in Turkey that the channel doesn't work in Mexico and Indonesia.

Keywords: Monetary Transmission Mechanism, Exchange Rate Channel, VAR Model.

\section{Gíriș}

Para politikası değișiklikleri, bazı mekanizmalar yoluyla ekonomiyi doğrudan ve dolaylı olarak etkileyebilmektedir. Para politikalarının gelir düzeyi ve genel fiyat düzeyi üzerindeki etkilerinin tahmin edilmesi, merkez bankasının uygulayacağı para politikalarının muhtemel etki ve sonuçlarının ekonomik birimlerin öngörebilmesi açısından önem arz etmektedir.

Parasal aktarım mekanizması (PAM) kavramı, bir ülkede para politikalarını yürütmekle yetkili kurumlarca uygulanan para politikası değișikliklerinin, toplam üretim, istihdam ve fiyatlar genel düzeyi gibi, ülke ekonomisinin tamamını ilgilendiren büyüklükler üzerindeki etkilerini açıklayan mekanizma olarak tanımlanmaktadır. PAM kavramı, önceleri para politikalarının sadece toplam talep ve toplam üretim üzerindeki etkileri olarak tanımlanır iken, günümüzde genel fiyat düzeyi üzerindeki etkileri de PAM kavramı içinde incelenmektedir (Halaç, 2015: 103-104). PAM'ın ișleyiși, bazı kanallar üzerinden gerçekleșmektedir. Literatürde, PAM kanalları farklı biçimlerde sınıflandırılmakla birlikte genel olarak, faiz, döviz kuru, varlık fiyatları ve kredi kanalları biçiminde sınıflandırılmaktadır (Mishkin, 1995: 4-9).

Bu çalıșmada incelenen ülkelerin tespit edilmesinde, iktisatçı Jim O'Neil'in ifade ettiği MINT ülke grubu sınıflandırması esas alınmıștır. Bu bağlamda Türkiye, Meksika ve Endonezya olmak üzere her üçülke de MINT ülkeleri içinde yer almakta olup, sahip oldukları makro ekonomik büyüklükler, siyasal ve demografik koșulların benzerliği yanında, yakın geçmiște enflasyon hedeflemesi rejimi uygulanmıș olması ve ekonomide geçirdiği evreler açısın- 
dan benzerlikler göstermektedir. Yakın geçmiște uygulanan istikrar programlarının bașarısızlıkla sonuçlanması ile birlikte, finans kaynaklı krizlerin ardından her üçülkede de para politikalarında önemli gelișmeler yașanmıștır.

Türkiye'de, Kasım 2000 ve Șubat 2001 krizlerinin ardından yürürlüğe konulan yapısal ve kurumsal reformların ardından 1211 sayılı Merkez Bankası Kanununda yapılan değișiklikler ile birlikte TCMB'ye para politikalarının yürütülmesinde amaç ve araç bağımsızlığı sağlanmıștır. Bu bakımdan TCMB, para politikalarında daha aktif bir konuma gelmiștir. 2002 yılından itibaren örtük ve 2006 yılından itibaren resmi olmak üzere enflasyon hedeflemesi rejimi uygulamasına bașlanmıștır.

Son yașanan 2007-2008 küresel Finans krizinin derinden etkilediği gelișmekte olan bazı ülkelerde kriz sonrasında para politikası uygulamalarında önemli dönüșümler gerçekleșmiștir. Bu bağlamda TCMB, küresel finans krizi sonrasındaki süreçte para politikalarında yeni bir amaç bileșeni olușturarak, fiyat istikrarı temel amacının yanı sıra finansal istikrarı da politika amacına dâhil etmiștir.

Çalıșmada incelenen diğer bir ülke Meksika'da, seksenli yıllardaki sabit kur rejimi temeline dayalı istikrar programı uygulamalarının ardından finansal serbestleșme süreci ve uygulanan para politikaları ile birlikte uluslararası sermaye akımları için uygun bir ortamın olușması sonucunda 1994 yilında para ve finans krizi ile karșılașmıștır. Krizin ardından toparlanma sürecine giren Meksika'da, Merkez Bankasının güvenirliliğini yeniden tesis etmek ve enflasyonist etkileri azaltmak amacıyla sıkı bir para politikası uygulanması ve Merkez Bankasının para politikası uygulamalarında șeffaflașmanın sağlanması kabul edilmiștir (Torres ve Saridakis, 2007: 2-3). 1995 yılında esnek kur rejimi uygulamasına geçilmiș, 1996 yılında yıllık bir enflasyon hedefinin belirlendiği, parasal tabandaki değișimi ve esnekliği esas alan yeni bir para programı uygulamaya konulmuștur. 2001 yılından itibaren enflasyon hedeflemesi rejimine geçilmiș, bu kapsamda, 2003 yılından itibaren yıllık yüzde üç oranında bir enflasyon hedefi belirlenmiș ve kısa vadeli faiz oranları politika faizi olarak belirlenmiștir. 2009 yılın- 
dan itibaren, ekonomik büyümenin yanında ulusal para biriminin istikrarının korunmasına yönelik para politikaları uygulanmıștır.

Çalıșmada incelenen üçüncü ülke Endonezya'da, Asya Krizi ile birlikte ulusal para birimi "Rupiah" yabancı paralar karșlsında ciddi oranda değer kaybetmiștir. Asya Krizi sonrasında Endonezya'da para politikalarında önemli bir değișim gerçekleșmiș olup, 1999 yılında Merkez Bankası Kanunu'nda yapılan değișiklik ile Merkez Bankası tarafından enflasyon hedefinin tespit edilmesine imkân veren amaç bağımsızlığı ve araç bağımsızlığının sağlanması kabul edilmiștir. Toparlanma sürecini geride bırakan Endonezya'da, 2002 yılından itibaren parasal hedefleme çerçevesi içinde bir para politikası uygulanmıș, 2005 yılından itibaren resmi enflasyon hedeflemesi rejimi uygulamasına bașlanmıștır. Krizin ardından Endonezya'da, para politikasının etkinliğini arttırmaya dönük alınan tedbirler çerçevesinde; operasyonel hedefin para tabanından politika faiz oranına geçilmesi, tutarlı bir karar alma sürecinin ortaya konulması, daha șeffaf bir iletișim stratejisi ve para politikası koordinasyonunun güçlendirilmesi kabul edilmiștir (Bank Indonesia, 2012: 31 ).

Son yașanan 2007-2008 Küresel Finans Krizinin ardından Endonezya'da 2010 yılında yeni bir para politikası çerçevesi olușturulmuș, bu kapsamda enflasyon hedeflemesinin yürütülmesinin yanında sermaye akımlarının yönetimi ve finansal sistemin istikrarına yönelik tedbirler alınmıștır.

Türkiye, Meksika ve Endonezya'da parasal aktarım mekanizması döviz kuru kanalının VAR Modeli yöntemiyle analiz edildiği bu çalıșmanın ilk bölümünde parasal aktarım mekanizması kanalları üzerine yapılan çalıșmalar incelenmiștir. İkinci bölümde, Türkiye, Meksika ve Endonezya'da parasal aktarım mekanizması döviz kuru kanalının Vektör Otoregresif (VAR) Modeli yöntemi ile ekonometrik analizi yapılmıștır. Son bölümde, elde edilen bulgular değerlendirilmiștir.

\section{Literatür İncelemesi}

Parasal akłarım mekanizması döviz kuru kanalının gelișmiș ve gelișmekte olan ülkelerdeki varlığı ve ișleyiși ile ilgili; Martínez vd. 
(2002), Altavilla (2004), Moschitz (2004), González ve García (2006), Hung (2007), Boivin vd. (2008), Butkiewicz ve Ozdogan (2009), Büyükakın vd. (2009), Örnek (2009), Boivin vd. (2010), Isakova (2010), Hespeler (2011), Zaidi (2011), Cambazoğlu ve Karaalp (2012), Nwosa ve Saibu (2012), Wulandari (2012), Kusuma ve Kassim (2013) önemli bulgular elde etmișlerdir.

Martínez vd. (2002), Meksika'da 1997-2000 döneminde parasal aktarım mekanizmasını incelemiștir. VAR Modeli yönteminin kullanıldığı çalıșmada, VAR modelinin belirlenmesinde reel döviz kuru, sanayi üretim endeksi, enflasyon oranı, reel faiz oranı ve hazine bonosu faiz oranı değișkenleri kullanılmıșıı. Çalıșma sonuçları 1997-2000 döneminde Meksika'da parasal aktarım mekanizmasının çalıștığına ișaret etmiștir.

Altavilla (2004), EURO Bölgesi ülkelerinde para politikası șoklarının reel GSYiH, enflasyon, faiz oranları ve döviz kuru üzerindeki etkilerini 1980-2002 dönemi için incelemiștir. Üçer aylık verilerin ve yapısal VAR Modeli yönteminin kullanıldığı çalıșmanın ekonometrik analizinde kullanılan değișkenler; reel çıkıı, uzun vadeli faiz oranları ve döviz kuru olarak belirlenmiștir. Calıșmada elde edilen sonuçlar, EURO Bölgesinde 1980-2002 döneminde para politikası șoklarının, reel GSYiH ve enflasyon üzerindeki etkisi negatif iken, kısa ve uzun vadeli faiz oranları üzerindeki etkisinin ise pozitif bulunmuștur. Ayrıca, döviz kurunun para politikası șokuna karșı tepkisinin zayıf olduğu tespit edilmiștir.

Moschitz (2004), Almanya, Fransa ve İtalya'da parasal aktarım mekanizmasını 1979-1998 dönemi için incelemiștir. Aylık verilerin kullanıldığı çalıșmada, VAR Modeli ve Hata Düzeltme Modeli (VECM) tahmini için belirlenen değișkenler; petrol fiyatla$\mathrm{rl}$, federal fon faiz oranı, sanayi üretimi, tüketici fiyat endeksi, dar tanımlı para arzı, yurtiçi faiz oranı ve döviz kuru olarak belirlenmiștir. VAR Modeli ve Hata Düzeltme Modeli (VECM) yöntemlerinin uygulandığı çalıșmada elde edilen bulgular, parasal aktarım mekanizmasının 1979-1998 dönemi için her üç ülkede de farklı olduğu, para politikası șoklarının çıktı ve fiyatlar üzerindeki etkisi Almanya'da zayıf iken Fransa'da daha etkili olduğu, para 
ve döviz kurunun etkisi ise her iki ülkede de güçlü olduğu tespit edilmiștir.

González ve García (2006), Meksika'da 1991-2005 döneminde parasal aktarım mekanizmasını incelemiștir. Doğrusal olmayan VAR modeli yönteminin uygulandığı çalıșmada VAR modellemesi için reel döviz kuru, enflasyon oranı, enflasyon beklentileri, nominal döviz kuru ve hazine bonosu faiz oranı değișkenleri kullanılmıștır. Çalıșma sonuçları Meksika'da 1991-2005 döneminde parasal aktarım mekanizmasının çalıștığına ișaret etmiștir.

Hung (2007), Vietnam ekonomisinde parasal aktarım mekanizmasını 1996-2005 dönemi için incelemiștir. Çalıșmada, para, reel çıkı, reel faiz oranı reel döviz kuru ve kredi ilișkileri analiz edilmiștir. Üçer aylık verilerin ve VAR modeli yönteminin kullanıldığı çalıșmada, VAR Modelinin tahmin edilmesinde reel endüstriyel üretim, tüketici fiyat endeksi ve geniș tanımlı para arzı değișkenleri içsel değișkenler olarak belirlenir iken, dünya petrol fiyatları, pirinç fiyatları ve federal fon faiz oranı değișkenleri dıșsal değișkenler olarak belirlenmiștir. Çalıșmada elde edilen sonuçlar, Vietnam ekonomisinde 1996-2005 döneminde para politikasının genel olarak üretim ve fiyatlar üzerinde etkili olduğuna ișaret eder iken, incelenen her bir kanalın istatistiksel olarak anlamlı olduğu ve özellikle de kredi ve döviz kuru kanallarının nispeten daha anlamlı olduğu sonucuna ulașılmıștır.

Boivin vd. (2008), Almanya, Fransa, İtalya, İspanya, Hollanda ve Belçika olmak üzere altı EURO Bölgesi ülkesinde, ortak para birimi EURO'ya geçiș ile birlikte parasal aktarım mekanizmasını ortak para birimi koșulları alıında incelemiștir. Çalıșmada 19802007 dönemi incelenmiș, üçer aylık veriler kullanılmıștır. FAVAR yönteminin uygulandığı çalıșmada, her bir ülke için 33 adet değișken kullanılmıștır. Çalıșmadaki değișkenler gruplandırıldığında, faiz oranı değișkenleri, reel döviz kuru, deflatör değișkenleri, gayri safi yurtiçi hasıla, tüketim harcaması değișkenleri, dıș ticaret değișkenleri, üretim ile ilgili değișkenler, fiyat endeksleri, istihdam ve ișgücü değișkenleri ile parasal büyüklük değișkenleri olarak belirlenmiștir. Boivin vd. (2008) çalıșmasında elde edilen sonuçlar, para politikası șoklarına karșı verilen tepkilerin 1980-2007 
döneminde EURO bölgesi ̈̈lkelerinde farklı olduğunu göstermiștir. Almanya faiz oranı șoklarıyla birlikte, İtalya ve İspanya'nın faiz oranı ve tüketim tepkisi Almanya'nın verdiği tepkiden daha güçlüdür. EURO'ya geçiș ile birlikte, aktarım mekanizması açısından bir homojenliğin ortaya çıkması ve parasal șokların etkilerinde bir azalma meydana geldiğini ortaya koymuștur.

Butkiewicz ve Ozdogan (2009), Türkiye ekonomisinde 1996-2007 döneminde özellikle 2000-2001 krizi sonrasında yapılan finansal yapı odaklı reformların, parasal aktarım mekanizması kanalları üzerindeki etkilerini ve para politikası hedeflerini gerçekleștirmedeki rolünü incelemiștir. Çalıșmada aylık veriler kullanılmıș olup, VAR Modeli yöntemi uygulanmıștır. Çalıșmanın VAR Modellemesinde yer alan değișkenler; para piyasası faiz oranı, tüketici fiyat endeksi, sanayi üretim endeksi ve dar tanımlı parasal büyüklük değișkeni olarak belirlenmiștir. Çalıșmada öncelikle, Türkiye'de yașanan 2000-2001 dönemi kriz öncesi 1996-1999 dönemi ele alınmıș; daha sonra 2000-2001 krizi sonrasını olușturan 2002-2007 dönemi incelenmiștir. Çalıșmada elde edilen bulgular, kriz sonrası Türkiye ekonomisinde uygulanan finansal reformları desteklediği, bu çerçevede para politikası șoklarının üretim üzerindeki etkisinin kriz sonrasında daha etkili olduğuna, fiyatlar üzerindeki etkisinin kriz öncesine göre giderek zayıfladığına ișaret etmiștir. Ayrıca Türkiye ekonomisinde 1996-2007 döneminde döviz kuru kanalının ekonomi üzerindeki etkisinin, kriz öncesi döneme göre kriz sonrası dönemde daha güçlü olduğu ortaya çıkmıștır. Varlık fiyatları kanalının her iki dönemde de aktif olmadığı, kredi kanalının ise oldukça zayıf ișlediği ve kriz öncesi dönemde sadece kısa vadede etkili olduğu tespit edilmiștir.

Büyükakın vd. (2009), Türkiye ekonomisinde 1990-2007 dönemi için parasal aktarım mekanizması döviz kuru kanalını incelemiștir. Çalıșmada aylık veriler kullanılmıș olup, VAR modeli yöntemi uygulanmıștır. Çalıșmanın VAR Modellemesi için kullanılan değișkenler; bankalararası para piyasası ișlemlerinde kullanılan gecelik basit faiz oranı, reel efektif döviz kuru endeksi, net ihracat, sabit fiyatlarla gayri safi yurtiçi hasıla, toptan eșya fiyatları endeksi olarak belirlenmiștir. Yapılan analizde, para politikası șoku karșısında 
reel döviz kuru, net ihracat, üretim ve fiyatların verdiği dinamik tepkiler tahmin edilmiștir. Çalıșmada elde edilen bulgular, Türkiye ekonomisinde, 1990-2007 döneminde para politikası șoklarının fiyatlar üzerinde etkili olduğunu ve döviz kurunun parasal aktarım mekanizmasında önemli bir rol oynadığını göstermiștir.

Örnek (2009) çalıșmasında, Türkiye'de para politikası șoklarının reel ekonomi ve fiyatlar üzerindeki etkileri, parasal aktarım mekanizması kanallarının ișleyiși ve bu kanalların etkin bir biçimde çalıșıp çalıșmadığı, 1990-2006 dönemi için üçer aylık veriler kullanılarak test edilmiștir. Bu kapsamda çalıșmada VAR Modeli yöntemi uygulanmıș olup, ekonometrik modellemede kullanılan değișkenler; reel GSYiH, bankalararası para piyasası basit faiz oranı, reel efektif döviz kuru, IMKB ulusal 100 endeksi, tüketici fiyat endeksi ve mevduat bankaları toplam kredileri olarak belirlenmiștir. Etki-tepki fonksiyonu ve varyans ayrıștırması sonuçları, Türkiye ekonomisinde 1990-2006 döneminde faiz oranı ve döviz kuru kanallarının anlamlı ve aktif olduğunu, varlık fiyatı ve kredi kanallarının anlamsız ve pasif olduğunu göstermiștir.

Boivin vd. (2010), ABD ekonomisinde 1962-1979 ve 19842008 dönemleri için parasal aktarım mekanizmasını incelemiștir. Aylık verilerin kullanıldığı ve FAVAR Yönteminin uygulandığı çalıșmada elde edilen bulgular, ABD ekonomisinde 1962-2008 döneminde, Neoklasik kanallar; faiz oranı, doğrudan yatırım harcamaları, servet ve tüketimde dönemler arası ikame etkili olurken, döviz kuru vasıtasıyla da ticareti etkilemektedir.

Isakova (2010), Kazakistan, Kırgızistan ve Tacikistan ekonomilerinde parasal aktarım mekanizması kanallarının etkinliğini incelemiștir. Merkezi plana dayalı ekonomik yapıdan piyasa ekonomisine geçiș ile birlikte önemli bir dönüșüm sürecini geride bırakan her üç ülkedeki parasal aktarım mekanizması faiz, döviz kuru ve banka kredi kanalları VAR Modeli Yöntemi ile incelenmiștir. Bu kapsamda, Kazakistan ve Kırgızistan için 2000-2008 dönemi, Tacikistan için 2002-2008 dönemi ele alınmıștır. Çalıșmada VAR modellemesi için belirlenen içsel değișkenler; reel gelir, fiyatlar, politika faiz oranı, parasal büyüklükler ve nominal döviz kuru olarak belirlenir iken, dıșsal değișkenler ise petrol fiyatları, alın 
fiyatları, pamuk fiyatları ve ABD federal fon faiz oranı değișkeni olarak belirlenmiștir. Çalıșmada elde edilen bulgular, 2000-2008 döneminde her üç ülkede de döviz kuru kanalının etkisinin güçlü olduğunu; faiz ve kredi kanallarının etkilerinin ise zayıf olduğunu ortaya koymuștur.

Hespeler (2011), Özbekistan ekonomisinde 2000-2009 döneminde parasal aktarım mekanizması kanallarının ișleyișini incelemiștir. Üçer aylık verilerin kullanıldığı, VAR ve VECM yöntemlerinin uygulandığı çalıșmada kullanılan içsel değișkenler; tüketici fiyat endeksi, reel GSYiH, reel döviz kuru, geniș tanımlı para arzı ve merkez bankası refinansman oranı olarak belirlenmiștir. Çalıșmanın sonuçları, Özbekistan ekonomisinde 2000-2009 döneminde faiz kanalının zayıf bir etkiye sahip olduğunu, döviz kuru kanalının ise güçlü bir etkiye sahip olduğunu göstermiștir.

Zaidi (2011), Malezya ekonomisinde 1982-2008 döneminde parasal aktarım mekanizması kanallarının ișleyișini incelemiștir. Çalıșmada, üçer aylık veriler kullanılmıș olup Yapısal VAR Modeli Yöntemi uygulanmıștır. Çalıșmada Yapısal VAR modeli tahmini için kullanılan değișkenler; reel GSYiH, enflasyon oranı, faiz oranı, reel kredi, reel varlık fiyatları, reel efektif döviz kuru değișkenleri yurtiçi değișkenler olarak belirlenir iken; reel emtia fiyatları, $A B D$ ve Japonya'ya ait reel GSYiH değișkenleri de yurtdıșı değișkenler olarak belirlenmiștir. Çalıșmada elde edilen bulgular, Malezya ekonomisinde 1982-2008 döneminde parasal aktarım mekanizması kredi kanalının yurtiçi üretim üzerinde önemli bir etkiye sahip olduğunu ortaya koyar iken, öte yandan döviz kuru kanalının enflasyon üzerinde önemli bir etkiye sahip olduğunu ortaya koymuștur.

Cambazoğlu ve Karaalp (2012), Türkiye'de 2003-2013 dönemi için parasal aktarım mekanizması döviz kuru kanalının toplam üretim ve fiyatlar üzerindeki etkilerini incelemiștir. Çalıșmada aylık veriler kullanılmıș olup, VAR modeli yöntemi uygulanmıștır. Çalıșmada VAR Modeli tahmininde kullanılan değișkenler; kısa vadeli faiz oranı, reel efektif döviz kuru, net ihracat hacmi, tüketici fiyat endeksi ve sanayi üretim endeksi olarak belirlenmiștir. Çalıșmada elde edilen sonuçlar, Türkiye ekonomisinde 2003-2013 
döneminde döviz kuru kanalının son derece aktif ve etkili bir kanal olduğunu göstermiștir. Bu bağlamda, döviz kuru kanalının parasal genișleme sonrasında reel değer kaybına neden olması toplam talebi pozitif yönde etkiler iken, enflasyon oranının da artmasına neden olmuștur.

Nwosa ve Saibu (2012), Nijerya ekonomisinde 1986-2009 döneminde parasal aktarımın faiz kanalının ve döviz kuru kanalının sektörel üretim artıșı üzerindeki etkisini incelemiștir. Çalıșmada, üçer aylık veriler ve kısısız VAR Modeli Yöntemi kullanılmıștır. Çalıșmada tahmin edilen altı değișkenli VAR Modeli denklem (1)'de verilmiștir.

$$
X_{t}=\left[Y^{t}, I N T, E X T, L P S C, L P C I, L A S P\right]^{t}
$$

Denklem (1)'deki değișkenler, sektörel üretim (Y), faiz oranı (INT), döviz kuru (EXT), yurtiçindeki toplam kredi (LPSC), tüketici fiyat endeksi (LCPI) ve varlık fiyat endeksi (LASP) olarak belirlenmiștir. Nwosa ve Saibu (2012)'nun çalıșmasında elde edilen bulgular, Nijerya ekonomisinde 1986-2009 döneminde, tarım ve imalat sektörleri açısından para politikası aktarımında faiz kanalının etkili olduğuna ișaret eder iken, döviz kuru kanalının ise yapı, inșaat, madencilik, hizmet ve toptan/perakende sektörlerinde zayıf da olsa etkili olduğuna ișaret etmiștir.

Wulandari (2012), Endonezya'da banka kredi ve faiz oranı kanallarının ișlerliğini Yapısal VAR modeli yöntemi ile incelemiștir. Çalıșmada elde edilen bulgular, incelenen her iki kanalın da aktif olarak çalıșığını ve özellikle de faiz oranı kanalııı parasal aktarım mekanizması içinde önemli bir rol oynadığını göstermiștir.

Kusuma ve Kassim (2013), Endonezya'da 1990-2009 döneminde döviz kuru kanalını incelemiștir. Standart VAR modeli yönteminin kullanıldığı çalıșmada; kriz öncesi dönem, kriz dönemi ve kriz sonrası dönem olmak üzere üç farklı bir biçimde incelemiștir. VAR Modellemesi için; nominal döviz kuru, enflasyon oranı, ihracat ve ithalat değișkenleri belirlenmiștir. Çalıșmada elde edilen bulgular, döviz kuru kanalının farklı tepkiler verdiğini göstermiștir. Buna göre, kriz sonrası ve enflasyon hedeflemesi uygulaması son- 
rasında döviz kuru kanalının düșük düzeyde tepki verdiği tespit edilmiștir.

Yukarıda incelenen parasal aktarım mekanizması döviz kuru kanalının gelișmiș ve gelișmekte olan ülkelerde varlığı ve ișleyiși ilgili çalıșmalar ayrıca Tablo 1 ve Tablo 2'de özetlenmiștir.

Tablo 1. Literatür Özeti-1

\begin{tabular}{|c|c|c|c|}
\hline Yazar & Ülke ve Dönem & Yöntem & Sonuç \\
\hline $\begin{array}{l}\text { Martínez vd. } \\
\text { (2002), }\end{array}$ & $\begin{array}{l}\text { Meksika } \\
\text { (1997-2000) }\end{array}$ & VAR & $\begin{array}{l}\text { Parasal aktarım mekanizmasının çalıștı- } \\
\text { ğı tespit edilmiștir. }\end{array}$ \\
\hline Altavilla (2004) & $\begin{array}{l}\text { EURO Bölgesi (1980- } \\
\text { 2002) }\end{array}$ & SVAR & $\begin{array}{l}\text { EURO Bölgesinde, parasal șokların } \\
\text { reel GSYiH ve enflasyon oranı üzerin- } \\
\text { deki etkisi negatiffir. Kısa ve uzun dö- } \\
\text { nem faiz oranları arasında, pozitif bir } \\
\text { ilișki bulunmuștur. }\end{array}$ \\
\hline Moschitz (2004) & $\begin{array}{l}\text { Almanya, Fransa, İtalya } \\
\text { (1979-1990) }\end{array}$ & $\begin{array}{l}\text { VAR } \\
\text { VECM }\end{array}$ & $\begin{array}{l}\text { Aktarım mekanizması, her üç ülkede de } \\
\text { farklıdır. Para politikası șoklarının çıktı } \\
\text { ve fiyatlar üzerindeki etkisi Almanya'da } \\
\text { zayıf iken, Fransa'da daha etkilidir. } \\
\text { Para ve döviz kurunun etkisi her iki ül- } \\
\text { kede de güçlüdür. }\end{array}$ \\
\hline $\begin{array}{l}\text { González ve } \\
\text { García (2006) }\end{array}$ & $\begin{array}{l}\text { Meksika } \\
\text { (1991-2005) }\end{array}$ & VAR & $\begin{array}{l}\text { Parasal aktarım mekanizmasının çalıștı- } \\
\text { ğı tespit edilmiștir. }\end{array}$ \\
\hline Hung (2007) & $\begin{array}{l}\text { Vietnam } \\
\text { (1996-2005) }\end{array}$ & VAR & $\begin{array}{l}\text { İncelenen her bir kanalın, istatistiksel } \\
\text { olarak anlamlı olduğu sonucuna ulașı- } \\
\text { mıștır. }\end{array}$ \\
\hline Boivin vd. (2008) & $\begin{array}{l}\text { Almanya, Fransa, İtal- } \\
\text { ya, İspanya, Hollanda, } \\
\text { Belçika } \\
\text { (1980-2007) }\end{array}$ & FAVAR & $\begin{array}{l}\text { EURO'ya geçiș ile birlikte, aktarım me- } \\
\text { kanizması açısından bir homojenliğin } \\
\text { ortaya çıkması ve parasal șokların etki- } \\
\text { lerinde bir azalma meydana geldiğini } \\
\text { ortaya koymuștur. }\end{array}$ \\
\hline \begin{tabular}{|l} 
Butkiewicz ve \\
Ozdogan (2009)
\end{tabular} & \begin{tabular}{|l} 
Türkiye \\
(1996-2007)
\end{tabular} & VAR & $\begin{array}{l}\text { Türkiye ekonomisinde kriz öncesi ve } \\
\text { sonrası döviz kuru kanalının ekonomi } \\
\text { üzerindeki etkisi kuvvetli iken kredi ka- } \\
\text { nalının etkisi zayıftır. Faiz kanalı ise pa- } \\
\text { rasal reformlar sonrasında etkili olduğu } \\
\text { tespit edilmiștir. }\end{array}$ \\
\hline \begin{tabular}{|l} 
Büyükakın vd. \\
(2009)
\end{tabular} & \begin{tabular}{|l} 
Türkiye \\
(1990-2007)
\end{tabular} & VAR & $\begin{array}{l}\text { Türkiye ekonomisinde } 1990-2007 \text { dö- } \\
\text { neminde para politikası șoklarının fiyat- } \\
\text { lar üzerinde etkili olduğu ve döviz kuru } \\
\text { kanalının parasal aktarım mekanizma- } \\
\text { sı içinde önemli bir rol oynadığı tespit } \\
\text { edilmiștir. }\end{array}$ \\
\hline
\end{tabular}




\begin{tabular}{|l|l|l|l|}
\hline Örnek (2009) & $\begin{array}{l}\text { Türkiye } \\
\text { (1990-2006) }\end{array}$ & VAR & $\begin{array}{l}\text { Türkiye ekonomisinde 1990-2006 dö- } \\
\text { neminde faiz oranı ve döviz kuru ka- } \\
\text { nallarının anlamlı ve aktif olduğu, varlık } \\
\text { fiyatı ve kredi kanallarının ise anlamsız } \\
\text { ve pasif olduğu tespit edilmiștir. }\end{array}$ \\
\hline Boivin vd. (2010) & $\begin{array}{l}\text { ABD } \\
(1962-1979) \\
(1984-2008)\end{array}$ & FAVAR & $\begin{array}{l}\text { Neoklasik kanallar faiz oranı doğru- } \\
\text { dan yatırım harcamaları servet ve tüke- } \\
\text { timde dönemler arası ikame etkili olur- } \\
\text { ken, döviz kuru vasıtasıyla da ticareti } \\
\text { etkilemektedir. }\end{array}$ \\
\hline Isakova (2010) & $\begin{array}{l}\text { Kazakistan } \\
(2000-2008) \\
\text { Kırgızistan } \\
(2000-2008) \\
\text { Tacikistan } \\
\text { (2002-2008) }\end{array}$ & $\begin{array}{l}\text { Her üç ülkede de döviz kuru kanalı çok } \\
\text { güçlü iken; faiz kanalı ve kredi kanalı- } \\
\text { nın etkileri zayıftır. }\end{array}$ \\
\hline
\end{tabular}

Tablo 2. Literatür Özeti-2

\begin{tabular}{|l|l|l|l|}
\hline Hespeler (2011) & $\begin{array}{l}\text { Özbekistan } \\
\text { (2000-2009) }\end{array}$ & $\begin{array}{l}\text { VAR } \\
\text { VECM }\end{array}$ & $\begin{array}{l}\text { Özbekistan ekonomisinde, faiz kanalı zayıf } \\
\text { iken döviz kuru kanalı daha güçlüdür. }\end{array}$ \\
\hline Zaidi (2011) & $\begin{array}{l}\text { Malezya } \\
\text { (1982-2008) }\end{array}$ & SVAR & $\begin{array}{l}\text { Malezya ekonomisinde, kredi kanalının yurtiçi } \\
\text { üretim üzerinde etkili olduğu, döviz kuru kana- } \\
\text { lının ise enflasyon oranı üzerinde önemli bir rol } \\
\text { oynadığı tespit edilmiștir. }\end{array}$ \\
\hline $\begin{array}{l}\text { Nwosa ve Saibu } \\
\text { (2012) }\end{array}$ & $\begin{array}{l}\text { Nijerya } \\
\text { (1986-2009) }\end{array}$ & VAR & $\begin{array}{l}\text { Elde edilen sonuçlar, tarım ve imalat sektörleri } \\
\text { açısından para politikası aktarımında faiz ka- } \\
\text { nalının etkin olduğunu göstermiștir. Döviz kuru } \\
\text { kanalı ise, yapı, inșaat madencilik, hizmetler ve } \\
\text { toptan/perakende sektörlerinde zayıf da olsa } \\
\text { etkilidir. }\end{array}$ \\
\hline Wulandari (2012) & Endonezya & SVAR & $\begin{array}{l}\text { Banka kredi ve faiz kanalları aktif olarak çalıș- } \\
\text { maktadır. }\end{array}$ \\
\hline $\begin{array}{l}\text { Kusuma ve Kassim } \\
\text { (2013) }\end{array}$ & $\begin{array}{l}\text { Endonezya } \\
\text { (1990-2009) }\end{array}$ & VAR & Döviz kuru kanalı aktifttir. \\
\hline
\end{tabular}

\section{Ekonometrik Analiz}

Bu çalıșmada kullanılan VAR modeli yöntemi, para politikasının etkilerini analiz etmede yaygın olarak kullanılan ekonometrik bir yöntemdir. VAR modeli sonuçlarından hareket ile elde edilen etki-tepki fonksiyonları, modeldeki değișkenlerden birine șok verilmesi durumunda belirli bir güven aralığı esas alınarak modeldeki diğer değișkenlerin șok karșısında verdiği tepkileri incelemektedir. 
Sims (1980), Almanya ve ABD ekonomilerinde para politikası șokları karșısında makroekonomik değișkenlerin gösterdiği tepkileri incelediği çalıșmasında VAR Modeli yöntemini önermiștir. Çalıșmada bazı değișkenler dıșsal olarak kabul edilmiș olup, Almanya için 1958-1976 dönemi, ABD için 1949-1975 dönemi incelenmiștir.

Bir eșitlik sisteminde açıklanan değișkenler, içsel (endogenous) değișken olarak nitelendirilirken, eșitlik sisteminde açıklayıcı konumunda bulunan değișkenler de dișsal (exogenous) değișken ya da önceden belirlenmiș değișken olarak nitelendirilir(Kutlar, 2000: 190). VAR Modeli yönteminde, bazı değișkenler dıșsal değișken olarak kabul edilmekte ve bu yöntem en küçük kareler tahmin yöntemine dayanmaktadır. Ekonometrik analizlerde yaygın olarak kullanılan en küçük kareler yöntemi kullanılarak yapılan VAR Modeli tahminleri, karmașık eșzamanlı eșitlik sistemlerinden daha iyi sonuçlar vermektedir. VAR Modeli yöntemi, kısıtlamaların en düșük düzeyde olduğu koșullarda para politikası șoklarının ekonomi üzerindeki etkilerini gösteren en iyi yöntem olarak belirtilmiștir (Örnek, 2009: 109-1 10).

VAR Modeli așağıda denklem (2)'de gösterilmiștir. Buna göre;

$$
X_{t}=A_{1} \chi_{t-1}+\ldots \ldots . .+A_{p} X_{t-p}+u_{t}
$$

(2) Nolu denklem $A_{i}(\mathrm{i}=1, \ldots \ldots ., \mathrm{P}),(\mathrm{K} \times \mathrm{K})$ boyutlu katsayı matrisi ve hata terimi süreci $u_{t}=\left(u_{l t} \ldots \ldots u_{K}\right)^{\prime} \mathrm{K}$ boyutunda, ortalaması sıfır, $\mathrm{E}\left(\mathrm{u}_{\mathrm{t}} \mathrm{u}_{\mathrm{t}}{ }^{\prime}\right)=\Sigma \mathrm{u}$ kovaryans matrisi ile birlikte beyaz gürültü sürecidir. Kısaca, ut iid (0, $\Sigma u)^{\prime}$ dir (Lütkepohl, 2007).

\subsection{Veri Seti ve Değișkenler}

Türkiye, Meksika ve Endonezya'da parasal aktarım mekanizması döviz kuru kanalının ekonometrik analizinin yapıldığı bu kısımda VAR Modeli yöntemi uygulanmıștır. Çalıșmada kullanılan verilerin temin edilmesinde IMF'nin yayınladığı IFS CD-ROM'dan ve IMF internet veri tabanından yararlanılmıștır. Ekonometrik analiz için kullanılan değișkenler ve veri seti ile ilgili bilgiler Tablo $3^{\prime}$ te gösterilmiștir. Çalıșmada kullanılan veriler üçer aylık olup, her üç ülke için de 2002:I-2016:IV dönemini kapsamaktadır. 
Tablo 3. Ekonometrik Analizi İçin Kullanılan Değișkenler ve Veri Seti Bilgileri

\begin{tabular}{|c|c|c|c|}
\hline Ülke & Değișken & Dönem & Açıklama \\
\hline \multirow{6}{*}{ 岂 } & SAN & 2002:Q1-2016:Q4 & $\begin{array}{l}\text { Sanayi Üretim Endeksi (Mevsimsel etkilerden arındı- } \\
\text { rılmıș) }(2005=100)\end{array}$ \\
\hline & RFO & 2002:Q1-2016:Q4 & Reel Faiz Oranı \\
\hline & HFE & 2002:Q1-2016:Q4 & Hisse Senedi Fiyat Endeksi $(2005=100)$ \\
\hline & \begin{tabular}{|l|l|} 
TÜFE \\
\end{tabular} & 2002:Q1-2016:Q4 & Tüketici Fiyat Endeksi $(2005=100)$ \\
\hline & NDK & 2002:Q1-2016:Q4 & Nominal Döviz Kuru \\
\hline & Kredi & 2002:Q1-2016:Q4 & Bankacılık Sektörü Yurtiçi Kredi Hacmi \\
\hline \multirow{5}{*}{$\begin{array}{l}\frac{\$}{\bar{\Xi}} \\
\text { 慈 } \\
\sum\end{array}$} & SAN & 2002:Q1-2016:Q4 & Sanayi Üretim Endeksi \\
\hline & $\mathrm{HFO}$ & 2002:Q1-2016:Q4 & Hazine Bonosu Faiz Oranı \\
\hline & HFE & 2002:Q1-2016:Q4 & Hisse Senedi Fiyat Endeksi $(2010=100)$ \\
\hline & TÜFE & 2002:Q1-2016:Q4 & Tüketici Fiyat Endeksi $(2005=100)$ \\
\hline & REDK & 2002:Q1-2016:Q4 & Reel Efektif Döviz Kuru \\
\hline \multirow{5}{*}{$\begin{array}{l}\underset{\nwarrow}{\mathbf{y}} \\
\text { 岁 } \\
\text { 号 }\end{array}$} & SAN & 2002:Q1-2016:Q4 & Sanayi Üretim Endeksi \\
\hline & $\mathrm{HFO}$ & 2002:Q1-2016:Q4 & Hazine Bonosu Faiz Oranı \\
\hline & TÜFE & 2002:Q1-2016:Q4 & Tüketici Fiyat Endeksi $(2005=100)$ \\
\hline & HFE & 2002:Q1-2016:Q4 & Hisse Senedi Fiyat Endeksi $(2010=100)$ \\
\hline & NDK & 2002:Q1-2016:Q4 & Nominal Döviz Kuru \\
\hline
\end{tabular}

Türkiye uygulaması için Tablo 3'te gösterilen; RFO (Reel Faiz Oranı), Kredi (Bankacılık Sektörü Yurtiçi Kredi Hacmi), SAN (Sanayi Üretim Endeksi (Mevsimsel etkilerden arındırılmıș) (2005=100)), TÜFE (Tüketici Fiyat Endeksi (2005=100)), HFE (Hisse Senedi Fiyat Endeksi $(2005=100)$ ) ve NDK (Nominal Döviz Kuru) olmak üzere altı değișkenli bir veri seti belirlenmiștir. Meksika uygulaması için; SAN (Sanayi Üretim Endeksi), HFO (Hazine Bonosu Faiz Oranı), HFE (Hisse Senedi Fiyat Endeksi $(2010=100)$ ), TÜFE (Tüketici Fiyat Endeksi (2005=100)) ve REDK (Reel Efektif Döviz Kuru) olmak üzere beș değișkenden olușan bir veri seti belirlenmiștir. Endonezya uygulaması için SAN (Sanayi Üretim Endeksi), HFO (Hazine Bonosu Faiz Oranı), HFE (Hisse Senedi Fiyat Endeksi $(2010=100))$, TÜFE (Tüketici Fiyat Endeksi $(2005=100))$ ve NDK (Nominal Döviz Kuru) olmak üzere beș değișkenden olușan bir veri seti belirlenmiștir. 
Çalıșmada kullanılan serilerin öncelikle, durağan olup olmadıklarını tespit etmek amacıyla birim kök testleri yapılmıștır.

\subsection{Birim Kök Analizi}

Çalıșmada kullanılan Türkiye'ye ait RFO serisi, Meksika ve Endonezya'ya ait HFO dıșındaki tüm serilerin logaritmik dönüșümleri yapılarak serilerin birim kök analizleri yapılmıștır. Serilerin birim kök analizinde, ADF (Genișletilmiș Dickey-Fuller) ve PP (Phillips-Perron) Birim Kök Test yöntemlerinden yararlanılmıștır. ADF Birim Kök Testinin uygulanmasında gecikme değerlerinin tespit edilmesinde "Schwarz Bilgi Kriteri" esas alınmıștır. Türkiye, Meksika ve Endonezya olmak üzere her üç ülkeye ait tüm serilerin ADF Birim Kök Test sonuçları Tablo 4'te gösterilmiștir.

Tablo 4. ADF (Genișletilmiș Dickey-Fuller) Birim Kök Test Sonuçları

\begin{tabular}{|c|c|c|c|c|c|c|}
\hline \multirow[b]{2}{*}{ Ülke } & \multirow[b]{2}{*}{ Değișken } & \multicolumn{2}{|c|}{ Düzey } & \multicolumn{2}{|c|}{ Birinci Fark } & \multirow[b]{2}{*}{ Sonuç } \\
\hline & & $\begin{array}{c}\text { Sabitli } \\
\text { Trendsiz }\end{array}$ & $\begin{array}{l}\text { Sabitli } \\
\text { Trendli }\end{array}$ & $\begin{array}{c}\text { Sabitli } \\
\text { Trendsiz }\end{array}$ & $\begin{array}{l}\text { Sabitli } \\
\text { Trendli }\end{array}$ & \\
\hline \multirow{6}{*}{ 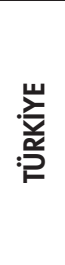 } & SAN & $-1.4124(0)$ & $-3.0162(1)$ & $-6.2583(0)^{*}$ & $-6.1798(0)^{*}$ & I(1) \\
\hline & RFO & $-2.3043(0)$ & $-2.0190(0)$ & $-5.7931(0)^{*}$ & $-5.8907(0)^{*}$ & I(1) \\
\hline & HFE & $-2.0500(1)$ & $-2.4235(1)$ & $-5.7287(0)^{*}$ & $-5.8493(0)^{*}$ & $1(1)$ \\
\hline & TÜFE & $-1.9363(5)$ & $-3.0399(5)$ & $-4.7769(3)^{*}$ & $-6.7657(4)^{*}$ & I(1) \\
\hline & NDK & $0.8238(0)$ & $-0.8742(0)$ & $-6.7409(0)^{*}$ & $-7.0687(0)^{*}$ & I(1) \\
\hline & Kredi & $-2.7052(3)$ & $-1.7910(3)$ & $-3.1386(2)^{* *}$ & $-4.0705(2)^{* *}$ & I(1) \\
\hline \multirow{5}{*}{$\begin{array}{l}\frac{\$}{\sqrt{5}} \\
\frac{\mathrm{w}}{\Sigma}\end{array}$} & SAN & $-1.0423(1)$ & $-3.0131(1)$ & $-4.4502(0)^{*}$ & $-4.4078(0)^{*}$ & I(1) \\
\hline & $\mathrm{HFO}$ & $-1.7149(1)$ & $-2.7930(1)$ & $-5.7631(0)^{*}$ & $-5.7156(0)^{*}$ & $1(1)$ \\
\hline & HFE & $-2.7765(2)$ & $-1.6631(1)$ & $-4.8325(0)^{*}$ & $-5.7337(1)^{*}$ & I(1) \\
\hline & TÜFE & $-1.4269(8)$ & $-0.5018(8)$ & $-5.0692(2)^{*}$ & $-3.5517(6)^{*}$ & I(1) \\
\hline & REDK & $-1.1100(0)$ & $-2.0070(0)$ & $-7.1797(0)^{*}$ & $-7.1427(0)^{*}$ & I(1) \\
\hline \multirow{5}{*}{$\begin{array}{l}\longleftarrow \\
\text { W } \\
\text { Ò } \\
\text { Z }\end{array}$} & SAN & $1.1135(3)$ & $-2.1302(0)$ & $-10.0326(2)^{*}$ & $-10.1940(2)^{*}$ & I(1) \\
\hline & $\mathrm{HFO}$ & $-2.9054(1)$ & $-2.3724(0)$ & $-3.6551(0)^{*}$ & $-3.6991(0)^{*}$ & I(1) \\
\hline & TÜFE & $-1.7109(0)$ & $-1.0383(0)$ & $-7.0040(0)^{*}$ & $-7.2999(0)^{*}$ & $1(1)$ \\
\hline & HFE & $-1.2862(1)$ & $-2.2847(1)$ & $-5.2677(0)^{*}$ & $-5.2756(0)^{*}$ & I(1) \\
\hline & NDK & $-0.5194(0)$ & $-2.0946(0)$ & $-7.0427(0)^{*}$ & $-6.0582(1)^{*}$ & I(1) \\
\hline
\end{tabular}

* : \%1 anlamllık düzeyinde alternatif hipotezin kabul edildiğini gösterir.

** : \%5 anlamlılık düzeyinde alternatif hipotezin kabul edildiğini gösterir.

Not : Parantez içindeki değerler gecikme değerlerini gösterir. 
Tablo 4'teki ADF Birim Kök Test sonuçlarına göre, tüm seriler $\% 1$ ve $\% 5$ anlamlılık düzeyleri ve sabitli-trendsiz ve sabitli-trendli olmak üzere her iki biçimde birinci farklara göre durağan oldukları [I(1)] ve birinci farkları alındığında birim kök içermedikleri sonucuna ulașılmıștır. Bu sonuca göre, birim kökün var olduğunu diğer bir ifade ile serinin durağan olmadığını iddia eden yokluk hipotezi $\left(\mathrm{H}_{0}\right)$ reddedilerek, birim kökün var olmadığını diğer bir ifade ile serinin durağan olduğunu iddia eden alternatif hipotez $\left(\mathrm{H}_{1}\right)$ kabul edilmektedir.

Her üç ülkeye ait serilere Phillips-Perron (PP) Birim Kök Testinin uygulanmasında, gecikme (lag) değerlerinin belirlenmesinde "Default (Bartlett kernel)" spectral tahmin yöntemi tercih edilmiș, "Newey-West Bandwidth" otomatik seçim esas alınmıı̦tır. PP birim kök test sonuçları ise Tablo $5^{\prime}$ te verilmiștir.

Tablo 5. PP (Phillips-Perron) Birim Kök Test Sonuçları

\begin{tabular}{|c|c|c|c|c|c|c|}
\hline \multirow[b]{2}{*}{ Ülke } & \multirow[b]{2}{*}{ Değișken } & \multicolumn{2}{|c|}{ Düzey } & \multicolumn{2}{|c|}{ Birinci Fark } & \multirow[b]{2}{*}{ Sonuç } \\
\hline & & $\begin{array}{c}\text { Sabitli } \\
\text { Trendsiz }\end{array}$ & $\begin{array}{l}\text { Sabitli } \\
\text { Trendli }\end{array}$ & $\begin{array}{c}\text { Sabitli } \\
\text { Trendsiz }\end{array}$ & $\begin{array}{l}\text { Sabitli } \\
\text { Trendli }\end{array}$ & \\
\hline \multirow{6}{*}{ 崖 } & SAN & $-1.4124(4)$ & $-2.8915(2)$ & $-6.0829(6)^{*}$ & $-5.9692(6)^{*}$ & I(1) \\
\hline & RFO & $-2.2853(3)$ & $-2.0994(4)$ & $-5.6802(5)^{*}$ & $-5.7023(8)^{*}$ & $1(1)$ \\
\hline & HFE & $-1.6406(2)$ & $-1.5521(0)$ & $-5.5989(5)^{*}$ & $-5.7100(7)^{*}$ & $1(1)$ \\
\hline & TÜFE & $-3.6793(3)^{*}$ & $-6.1337(3)^{*}$ & - & - & $1(0)$ \\
\hline & NDK & $0.8041(3)$ & $-0.7413(4)$ & $-6.7441(2)^{*}$ & $-7.8125(7)^{*}$ & $1(1)$ \\
\hline & Kredi & $-2.2068(3)$ & $-0.7263(3)$ & $-6.0131(3)^{*}$ & $-6.8480(1)^{*}$ & I(1) \\
\hline \multirow{5}{*}{$\begin{array}{l}\frac{\$}{\sqrt{5}} \\
\text { 姜 }\end{array}$} & SAN & $-0.9943(2)$ & $-2.2750(3)$ & $-4.4874(3)^{*}$ & $-4.4458(3)^{*}$ & I(1) \\
\hline & $\mathrm{HFO}$ & $-1.4684(0)$ & $-2.1463(1)$ & $-5.7914(2)$ & $-5.7444(2)$ & $1(0)$ \\
\hline & HFE & $-0.9050(3)$ & $-1.9837(0)$ & $-4.9646(8)^{*}$ & $-4.9238(9)^{*}$ & $1(1)$ \\
\hline & TÜFE & $-1.9742(8)$ & $-2.1256(11)$ & $-7.6804(8)^{*}$ & $-8.2913(8)^{*}$ & I(1) \\
\hline & REDK & $-1.1653(2)$ & $-2.2740(3)$ & $-7.1797(0)^{*}$ & $-7.1427(0)^{*}$ & I(1) \\
\hline \multirow{5}{*}{ 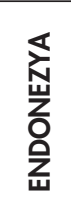 } & SAN & $-0.9307(8)$ & $-4.5484(1)^{*}$ & $-14.1391(8)^{*}$ & $-15.2908(8)^{*}$ & $1(1)$ \\
\hline & $\mathrm{HFO}$ & $-2.4463(3)$ & $-2.7443(3)$ & $-3.8070(1)^{*}$ & $-3.8599(1)^{* *}$ & I(1) \\
\hline & TÜFE & $-1.7640(4)$ & $-1.0476(3)$ & $-7.0058(2)^{*}$ & $-7.3072(5)^{*}$ & $1(1)$ \\
\hline & HFE & $-1.5950(4)$ & $-1.8020(3)$ & $-5.0143(6)^{*}$ & $-4.9511(7)^{*}$ & $1(1)$ \\
\hline & NDK & $-0.5693(2)$ & $-2.2064(1)$ & $-7.0739(5)^{*}$ & $-7.0603(5)^{*}$ & $1(1)$ \\
\hline
\end{tabular}

* : ADF ve PP \%1 anlamlılık düzeyinde alternatif hipotezin kabul edildiğini gösterir.

** : ADF ve PP \%5 anlamlılık düzeyinde alternatif hipotezin kabul edildiğini gösterir.

Not :Parantez içindeki değerler gecikme değerlerini gösterir. 
Tablo 5'teki sonuçlara göre, Türkiye'ye ait TÜFE ve Meksika'ya ait HFO serileri düzey değerleri ile durağan [I(O)] olarak sonuçlanmıș olup, diğer tüm değișkenlere ait tüm seriler birinci fark değerleri ile durağan [I(1)] olarak sonuçlanmıștır. Birim kök test sonuçları her iki yönteme göre değerlendirildiğinde ADF ve PP sonuçları arasında Türkiye'ye ait TÜFE ve Meksika'ya ait HFO serileri açısından bir farklılık ortaya çıkmıștır. Böyle bir durumda, ADF Birim Kök Test sonuçları esas alınmıștır.

\subsection{VAR Modeli Etki-Tepki Fonksiyonu Analizi}

VAR Modeli etki-tepki fonksiyonu sonuçları grafikleri döviz kuru kanalı açısından Grafik 1, Grafik 2 ve Grafik 3'te gösterilmiștir. Türkiye'ye ait sonuçlar Grafik 1, (A) ve (B) panellerinde gösterilmiștir. Bu kapsamda yüzde 95 güven aralığı için NDK değișkeninin hata terimlerine bir standart sapmalık dıșsal bir șok uygulandığında (A) panelinde SAN değișkeninin bu șoka karșı tepkisi istatistiksel olarak anlamsız olarak gerçekleșmiș olup Grafik 1, (B) panelinde TÜFE değișkeninin tepkisi pozitif ve anlamlı olarak sonuçlanmıș ikinci dönemde maksimumdur. İkinci dönemden sonra sözkonusu etki giderek sönmüștür. Elde edilen bu sonuçlar Türkiye'de parasal aktarım mekanizması döviz kuru kanalının kısmen çalıștığına ișaret etmiștir.

(A)

SAN değișkeninin NDK değișkenine tepkisi

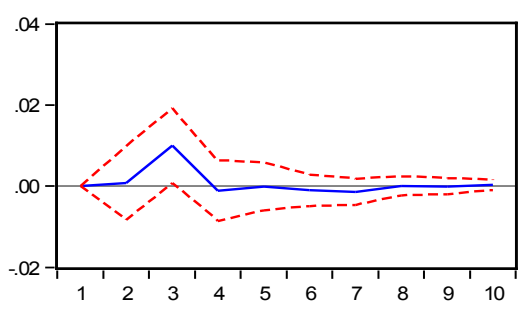

(B)

TÜFE değișkeninin NDK değișkenine tepkisi

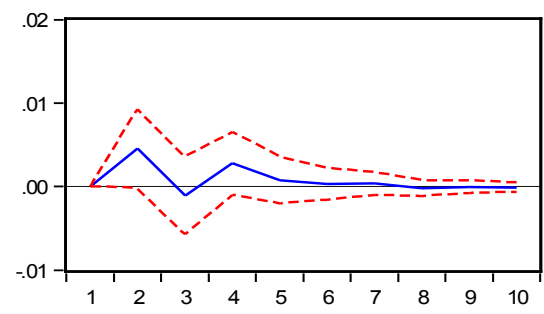

Grafik 1. VAR Modeli Etki-Tepki Fonksiyonu Sonuçları (Türkiye) 
Meksika'ya ait VAR Modeli etki-tepki fonksiyonu sonuçları Grafik 2, (A) ve (B) panellerinde gösterilmiștir. Buna göre REDK değișkeninin hata terimlerine bir standart sapmalık dıșsal bir șok uygulandığında, (A) panelinde SAN değișkeninin tepkisinin ve (B) panelinde TÜFE değișkeninin tepkisinin istatistiksel olarak anlamsız olduğu sonucuna ulașılmıștır. Bu ekonometrik sonuçlara göre, Meksika'da parasal aktarım mekanizması döviz kuru kanalının etkisiz olduğu ortaya çıkmıștır.

(A)

SAN değișkeninin REDK değișkenine tepkisi

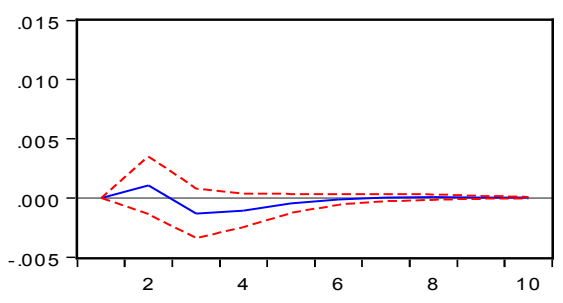

(B)

TÜFE değișkeninin REDK değișkenine tepkisi

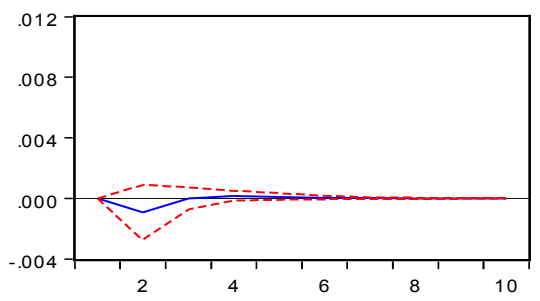

Grafik 2. VAR Modeli Etki-Tepki Fonksiyonu Sonuçları (Meksika)

Grafik 3, (A) ve (B) panellerinde Endonezya'ya ait VAR Modeli etki-tepki fonksiyonu sonuçları gösterilmiștir. Elde edilen ekonometrik sonuçlara göre, NDK değișkenine bir standart sapmalık dıșsal bir șok uygulandığında, SAN değișkeninin söz konusu dıșsal șok karșısında verdiği tepki anlamsız olarak gerçekleșmiș ve (A) panelinde gösterilmektedir. TÜFE değișkeninin tepkisi istatistiksel olarak anlamsız olarak gerçekleșmiș olup (B) panelinde gösterilmiștir. Elde edilen ekonometrik sonuçlar, Endonezya'da parasal aktarım mekanizması döviz kuru kanalının çalıșmadığını göstermiștir. 
(A)

SAN değișkeninin NDK değișkenine tepkisi

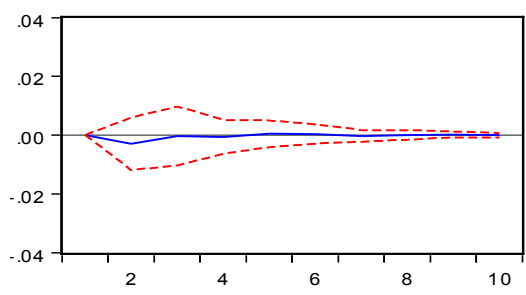

(B)

TÜFE değișkeninin NDK değișkenine tepkisi

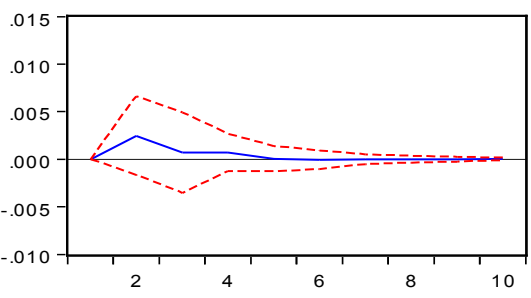

Grafik 3. VAR Modeli Etki-Tepki Fonksiyonu Sonuçları (Endonezya)

Çalıșmada elde edilen ekonometrik sonuçlar, parasal aktarım mekanizması döviz kuru kanalının Türkiye'de kısmen çalıștığını, Meksika'da ve Endonezya'da ise söz konusu kanalın çalıșmadığını ortaya koymuștur.

\section{Sonuç}

Bu çalıșmada Türkiye, Meksika ve Endonezya ekonomilerinde, VAR Modeli yöntemi kullanılarak parasal aktarım mekanizmasının döviz kuru kanalının etkinliği incelenmiștir. Bu kapsamda, Türkiye için altı değișkenli, Meksika ve Endonezya için beș değișkenli VAR modelleri tahmin edilmiș, etki-tepki fonksiyonu grafikleri yorumlanmıștır. Elde edilen bulgular, döviz kuru kanalının incelenen ülkelerden Türkiye'de kısmen çalıștığını, Meksika'da ve Endonezya'da ise söz konusu kanalın çalıșmadığını ortaya koymuștur.

Parasal aktarım mekanizması kanalları ișleyiș ve etkinlik yönünden ülkeden ülkeye farklılıklar göstermektedir. Uygulanan para politikaları, finansal sistemin yapısı ve derinliği, ülke ekonomisinin dıșa açıklık düzeyi gibi faktörler parasal aktarım mekanizmasının ișleyișini etkilemektedir.

Bu çalıșmada, Türkiye, Meksika ve Endonezya olmak üzere toplam üç ülke analize dâhil edilmiștir. Analizde üçülkenin incelenmesinin nedeni, her üç ülke ekonomisi arasında geçmișten günümüze uygulanan para politikaları ile ekonomik ve finansal koșullar açısından benzerliklerin bulunmasıdır. Her üç ülkede, gü- 
nümüzde enflasyon hedeflemesi rejimi uygulamasına devam edilmektedir.

Son yașanan ve dünya ekonomisini olumsuz etkileyen küresel finans krizi sonrasında, para politikalarında merkez bankalarına yeni bir rol yüklenmiș ve fiyat istikrarının yanı sıra finansal istikrar da zorunlu bir amaç olarak görülmeye bașlanmıștır. Ayrıca bu amaçların gerçekleștirilmesine dönük, yeni para politikası araçları ile ilgili arayıștar tartıșılmıștır. Fiyat istikrarı ile birlikte finansal istikrarın gerçekleștirildiği bir ekonomide, para politikalarının ekonomi üzerindeki özellikle de üretim ve fiyatlar üzerindeki etkileri olumlu yönde gelișecektir.

Butkiewicz ve Ozdogan (2009), Büyükakın (2009), Örnek (2009), Türkiye'de döviz kuru kanalının varlığı ve ișleyișini VAR Modeli yöntemiyle incelediği çalıșmasında, Türkiye'de parasal aktarım mekanizması döviz kuru kanalının ișlediği yönünde bulgulara ulașmıșlardır.

Bu çalıșmada VAR yönteminden hareket ile elde edilen etkitepki fonksiyonu sonuçları, Butkiewicz ve Ozdogan (2009), Büyükakın vd. (2009), Örnek (2009)'in Türkiye'de parasal aktarım mekanizması ve kanallarını incelediği çalıșmasında bulduğu sonuçlar ile örtüșmektedir.

Çalıșmada elde edilen bulgular ıșığında, her üç ülke merkez bankasının da para politikası uygulamalarında aktif bir rol yüklenmeye devam etmesi gerekmektedir. Merkez bankalarının fiyat istikrarı amacının yanı sıra finansal istikrar amacını da benimsemiș olması ve söz konusu amaçlara uygun yeni para politikası araçlarını uygulamaya koyması yanında, enflasyon hedeflemesi rejiminin sürdürülmesi parasal aktarım mekanizmasının ișleyiși açısından önem arz etmektedir. 


\section{KAYNAKLAR}

Affandi, Y. 2004. Estimating Policy Rule in Post Crisis Indonesia. Faculty of Economics and Politics, St Edmund's College, University of Cambridge. 1-19, https://www .researchgate.net/publication/265200762_Estimating_Monetary_Policy_Rule_in_Post_Crisis_Indonesia (erișim tarihi: 25.09.2014)

Altavilla, C. 2004. Monetary Policy Implementation and Transmission Mechanisms in the Euro Area, Faculty of Economics. Dissertation series K.U.Leuven 192.

Banco De México. 2012. Annual Report 2012. http://www.banxico. org. $\mathrm{mx} /$ publicaciones-y-discursos/publicaciones/informes-periodicos/ anual/\%7BBFE109E9-2B81-B4DC-360 E-1DC9704B6919\%7D.pdf (erișim tarihi: 25.09 .2014 )

Bank Indonesia. 2012. http://www.seacen.org/GUI/pdf/publications/ bankwatch/2012/5BI.pdf (erișim tarihi: 12.11.2013)

Boivin, J., Giannoni, M.P. ve B. Mojon. 2008. How Has the Euro Changed The Monetary Transmission?. NBER Working Papers 14190. National Bureau of Economic Research Inc.

Boivin, J., Kiley, M. ve F.S. Mishkin. 2010. .How Has the Monetary Transmission Mechanism Evolved Over Time?. NBER Working Papers 15879. National Bureau of Economic Research Inc.

Butkiewicz, J. L. ve Z. Ozdogan. 2009. Financial Crisis, Monetary Policy Reform and The Monetary Transmission Mechanism in Turkey. Working Paper Series 2009-04. Department of Economics. Alfred Lerner College of Business \& Economics, University of Delaware.

Büyükakın, F., Cengiz, V. ve A. Türk. 2009. Parasal Aktarım Mekanizması: Türkiye'de Döviz Kuru Kanalının VAR Analizi. Dokuz Eylül Üniversitesi İktisadi ve İdari Bilimler Fakültesi Dergisi. 1(24): 171-198.

Cambazoğlu, B. ve H.S. Karaalp. 2012. Parasal Aktarım Mekanizması Döviz Kuru Kanalı: Türkiye Örneği. Yönetim ve Ekonomi. 19(2): 53-66.

González, A. G. ve J. R. G. García. 2006. Structural Change in the Transmission Mechanism of Monetary Policy in Mexico: A Non-Linear VAR Approach. Bank of Mexico Working Paper No:6.

Halaç, U. 2015. Parasal Aktarım Mekanizması. Para İktisadı. Editör: N. Oğuzhan Altay. Ankara: Palme Yayıncilık.

Hespeler, F. 2013. A VECM Evaluation of Monetary Transmission in Uzbekistan. Economic Change and Restructuring. Springer 46(2): 219-253. 
Hung, L. V. 2007. A Vector Autoregression (VAR) Analysis of the Monetary Transmission Mechanism in Vietnam. http://www.grips.ac.jp/vietnam/VDFTokyo/Doc/35LVHung 18Aug07Paper.pdf . (erișim tarihi: 08.10.2014)

Isakova, A. 2010. Monetary Policy, Inflation and Dollarization in the Economies of Central Asia. Doktora Tezi, Center for Economic Research and Graduate Education Charles University. Prague. March 2010.

Kusuma, D. B. W. ve S. H. Kassim. 2013. Evaluating Monetary Transmission Mechanism in Indonesia Through Exchange Rate Channel. Jurnal Ekonomi dan Studi Pembangunan, 14(2). 91-100.

Kutlar, A. 2000. Ekonometrik Zaman Serileri: Teori ve Uygulama. Ankara: Gazi Yayınları.

Lütkepohl, H. 2007. Econometric Analysis with Vector Autoregressive Models. EUI Working Papers. ECO 2007/1 1: 1-56.

Martínez, L., Sánchez, O. ve A Werner. 2002. Monetary policy and the Transmission Mechanism in Mexico. Bank of International Settlement Papers, 8.

Mishkin, F. 1995. Symposium on the Monetary Transmission Mechanism. Journal of Economics Perspective. 3(9): 3-10

Moschitz, J. 2004. Essays on the Transmssion Mechanism of Monetary Policy. Universitat Autonoma de Barcelona Department D'economia D'Hıstoria Economica. June 2004.

Nwosa, P. I. ve M. O. Saibu. 2012. The Monetary Transmission Mechanism in Nigeria: A Sectoral Output Analysis. International Journal of Economics and Finance. 1(4): 204-212.

Örnek i. 2009. Türkiye'de Parasal Aktarım Mekanizması Kanallarının İșleyiși. Maliye Dergisi, 156 (1): 104-125.

Sims, C. A. 1980. Macroeconomics and Reality. Econometrica. 48: 1-48.

Torres, R. I. M. ve G. Saridakis. 2007. Inflation Targeting in Emerging Economics: The Case of Israel and Mexico. University of Leicester and for the Money, Macro and Finance Research Group (MMF) Conference for Comments and Suggestions.

Wulandari, R. 2012. Do Credit Channel and Interest Rate Channel Play Important Role in Monetary Transmission Mechanism in Indonesia?: A Structural Vector Autoregression Model. Prodecia-Social Behavioural Science 65. 557-563.

Zaidi, M.A.S.B. 2011 . Structural Vector Autoregressive Analysis of Monetary Policy in Malaysia. PhD. Thesis. Australian School of Business University of New South Wales, The Australian School of Business The University of New South Wales. 